solution was inoculated to twelve half-leaves distributed equally on each plant and at each leaf position. After inoculation, six plants were exposed to daylight and six put in darkness. The greater relative infectivity of the irradiated nucleic acid in plants in the light is obvious. With or without photoreactivation, inactivation approximately follows first-order kineties, with photoreactivation equivalent to halving the dose of radiation. This factor of two places the nucleic acid of tobacco mosaic virus second only to potato virus $X$ when plant viruses are listed according to the extent they show photoreactivation ${ }^{1}$, but as the other viruses were irradiated only when intact, their nucleic acids might show the phenomenon more strongly if irradiated free from their protein.

MeLaren and Takahashi ${ }^{2}$ found that the infectivity of nucleic acid preparations was halved when $1 \mathrm{mgm}$. absorbed 0.43 joule. They do not say how their inoculated plants were treated, but it is likely they were placed in the light, for this value is close to the $0 \cdot 38$ joule which can be calculated from the data in Table 2 for plants in the light, whereas the value for 50 per cent inactivation without photoreactivation is $0 \cdot 19$.

Siegel, Wildman and Ginozas concluded that the differences between sensitivity of different strains of tobacco mosaic virus reside in the nature of the bonding between the protein and nucleic acid. As none of the strains yet tested, although they differ in their sensitivity to inactivation, shows photoreactivation when irradiated intact, all seem to share a type of bonding that protects the nucleic acid from changes reversed by light. We have not attempted to see whether recombining separated nucleic acid with the protein would prevent photoreactivation, but the type of bonding in 'reconstituted' virus particles seems to differ from that in the original virus because the recombination does not restore the original degree of resistance to inactivation by irradiation ${ }^{3}$. Even the most sensitive strain of tobacco mosaic virus requires much more energy to be inactivated than does potato virus $X$, which has the same content of nucleic acid. It seems, then, that the nucleic acids of different viruses may resemble one another in sensitivity to irradiation and in undergoing more than one type of change, but that their proteins protect them to very different extents from changes of different kinds. It is possible that we have not measured the full potential of tobacco mosaic virus to be photoreactivated, for separating the nucleic acid from its protein may have changed some of the groups that otherwise could have undergone reversible changes.

We used two low-pressure mercury lamps, both of which have most of their radiation of wave-length $254 \mathrm{~m} \mu$, and one of which had a filter excluding wave-lengths shorter than $240 \mathrm{~m} \mu$. Both gave qualitatively similar results : photoreactivation when the separated nucleic acid was irradiated, but not when intact virus was, whether the inoculum was intact virus or nucleic acid separated from the irradiated virus.

${ }^{1}$ Bawden, F. C., and Kleczkowski, A., J. Gen. Microbiol., 18, 370 (1955).

"McLaren, A. D., and Takahashi, W. N., Radiation Res., 6, 532 (1957) ${ }^{3}$ Siegel, A., Wildman, S. G., and Ginoza, W., Nature, 178, 1117 (1956)

${ }^{4}$ Fraenkel-Conrat, H., J. Amer. Chem. Soc., 78, 882 (1956).

${ }^{5}$ Glerer, A., and Schramm, G., Nature, 177, 702 (1956).

\title{
OBITUARIES
}

\section{Sir Claude Gibb, K.B.E., F.R.S.}

Sir Claude Drxon GibB, who died suddenly in the United States on January 15, was one of the outstanding engineers of our time. $\mathrm{He}$ was also pre-eminent as an administrator, manufacturer and scientist. He was sixty years of age.

After qualifying at the University of Adelaide, he became a senior research assistant in the Engineering Laboratory there after a short interruption as a pilot in the Royal Australian Flying Corps. He went to Great Britain in 1924 to gain experience as a fitter with the firm of Messrs. C. A. Parsons and Co., Ltd. Such was his ability that he was made general manager in 1937 and managing director in 1943. In 1940, loaned by his Company to the Ministry of Supply, he rapidly moved from engineering assistant to director-general, Munitions Production, and afterwards to director-general, Armoured Fighting Vehicles, and chairman of the Tank Board.

He was elected a Fellow of the Royal Society in 1946 and has been noted for his particular interest in research, originally on steam turbine components and latterly in nuclear work for the production of power. In 1946 he was appointed a member of the Board of the National Physical Laboratory, and became a member of the Council of King's College, Newcastle upon Tyne, in the same year.

In 1947 Sir Claude was appointed a member of the Advisory Council on Seientific Policy and became chairman of the Committee on Research and Pro. ductivity. He has also been chairman of the Sectional Cornmittee on Engineering of the Royal Society and was a member of the Mechanical Engineering Research Board of the Department of Scientific and Industrial Research. In 1949 he was a vice-president of the British Association and in 1951 president of Section $G$ (Engineering) of the Association. He was also chairman of the Board of Governors of the Rutherford College of Technology.

Sir Charles's own scientific work has been described in technical papers given to the major institutions in Canada, Australia and the United Kingdom. Under him, Messrs. C. A. Parsons have an order for a $550 \mathrm{MW}$. set for the Thorpe Marsh Power Station at this time the largest in the world. As a result of his work, this Company became the main contractors for the first nuclear power station, namely, Calder Hall. The Company has also been engaged in the very large items of equipment for Chapelcross Power Station and the large new power station under construction at Bradwell. Sir Claude was also mainly instrumental in the negotiations in Italy to build a nuclear power station at Latina, near Rome.

Sir Claude received many well-deserved honours. Such is the brilliant record of a man who from funda. mental knowledge of science with a strong basis of practical imagination brought so much honour to the firm and country which he chose as his own.

T. W. F. Brown 